\title{
OBSESSIVE-COMPULSIVE DISORDER AMONG AFRICAN AMERICANS AND BLACKS OF CARIBBEAN DESCENT: RESULTS FROM THE NATIONAL SURVEY OF AMERICAN LIFE
}

Joseph A. Himle, Ph.D., ${ }^{1,2 *}$ Jordana R. Muroff, Ph.D. ${ }^{3}$ Robert Joseph Taylor, Ph.D., ${ }^{1}$ Raymond E. Baser, M.S., ${ }^{4}$ Jamie M. Abelson, M.S.W., ${ }^{4}$ Gregory L. Hanna, M.D., ${ }^{1}$ James L. Abelson, M.D. Ph.D., ${ }^{1}$ and James S. Jackson, Ph.D. ${ }^{4,5}$

Background: There is limited research regarding the nature and prevalence of obsessive-compulsive disorder (OCD) among various racial and ethnic subpopulations within the United States, including African Americans and blacks of Caribbean descent. Although beterogeneity within the black population in the United States has largely been ignored, notable differences exist between blacks of Caribbean descent and African Americans with respect to etbnicity, national heritage, and living circumstances. This is the first comprehensive examination of OCD among African Americans and blacks of Caribbean descent. Methods: Data from the National Survey of American Life, a national bousebold probability sample of African Americans and Caribbean blacks in the United States, were used to examine rates of OCD among these groups. Results: Lifetime and 12month OCD prevalence estimates were very similar for African Americans and Caribbean blacks. Persistence of OCD and rates of co-occurring psychiatric disorders were very high and also similar between African American and Caribbean black respondents. Both groups had high levels of overall mental illness severity and functional impairment. Use of services was low for both groups, particularly in specialty mental health settings. Use of anti-obsessional medications was also rare, especially among the Caribbean black OCD population. Conclusions: OCD among African Americans and Caribbean blacks is very persistent, often accompanied by other psychiatric disorders, and is associated with bigh overall mental illness severity and functional impairment. It is also likely that very few blacks in the United States with OCD are receiving evidence-based treatment

\footnotetext{
${ }^{1}$ Department of Psychiatry, University of Michigan, Ann Arbor, Michigan

${ }^{2}$ University of Michigan School of Social Work, Ann Arbor, Michigan

${ }^{3}$ Boston University School of Social Work, Boston, Massachusetts

${ }^{4}$ University of Michigan Institute for Social Research, Ann Arbor, Michigan

${ }^{5}$ Department of Psychology, University of Michigan, Ann Arbor, Michigan
}

Contract grant sponsor: National Institute of Mental Health; Contract grant number: U01-MH57716; Contract grant sponsor: National Institutes of Health.

*Correspondence to: Joseph A. Himle, Ph.D., University of Michigan Department of Psychiatry, Rachel Upjohn Building, 4250 Plymouth Rd. Ann Arbor, Ml 48109-5763.

E-mail: himlej@umich.edu

Received for publication 20 June 2007; Revised 26 September 2007; Accepted 17 October 2007

DOI 10.1002/da.20434

Published online 2 October 2008 in Wiley InterScience (www.interscience.wiley.

com).

†This article is a US Government work and as such, is in the public domain in the United States of America.

Published 2008 Wiley-Liss, Inc. 
and thus considerable effort is needed to bring treatment to these groups.

Depression and Anxiety 25:993-1005, 2008. Published 2008 Wiley-Liss, Inc. ${ }^{\dagger}$

Key words: OCD; anxiety; race; ethnicity; epidemiology; prevalence

\section{INTRODUCTION}

$\mathbf{O}$ bsessive-compulsive disorder (OCD) is an anxiety disorder characterized by recurrent and persistent ideas, thoughts, or images that are experienced as intrusive and inappropriate (obsessions), and/or repetitive behaviors or mental acts that a person feels driven to perform in response to an obsession or discomfort (compulsions). ${ }^{[1]}$ OCD is a chronic illness that persists in $60-80 \%$ of cases. ${ }^{[2,3]}$ Adults with OCD delay an average of 7.5 years before presenting for treatment. ${ }^{[4]}$ Epidemiologic and clinical samples of adults with OCD have demonstrated a substantial amount of psychiatric comorbidity with an average of $50-75 \%$ of adults meeting the criteria for another lifetime psychiatric disorder. ${ }^{[5,6]}$

OCD is associated with significant economic and functional impairment. OCD places tenth in overall global disease burden (combined measure of deaths, impact of premature death, and disability) as reported by the World Health Organization. ${ }^{[7]}$ OCD sufferers often experience substantial impairments in employment, ${ }^{[8]}$ educational attainment, ${ }^{[9-11]}$ social relationships ${ }^{[8]}$ family functioning, ${ }^{[12,13]}$ and cognitive abilities. ${ }^{[14,15]}$ Finally, U.S. Census data suggest that $\$ 8.4$ billion per year are spent for the management of OCD. ${ }^{[8]}$

Data from the National Comorbidity Replication Survey (NCS-R) estimates an overall lifetime prevalence rate of OCD of $1.6 \%$ and 12 -month prevalence of $1.0 \%$ in the United States. ${ }^{[16]}$ Early cross-national epidemiologic studies ${ }^{[17]}$ found similar rates of OCD in several countries ${ }^{[18]}$ but more recent reviews highlight considerable cross-cultural differences in lifetime and 12-month OCD rates. ${ }^{[19]}$ Cross-cultural differences are also observed in OCD symptom profiles. ${ }^{[20,21]}$ Overall, the nature and rate of OCD appears to vary meaningfully across cultures but this conclusion is tempered by considerable methodological variations across studies.

There is limited research regarding the nature and prevalence of OCD among various racial and ethnic subpopulations within the United States, including African Americans. Similar relative rates of OCD between non-Hispanic black and non-Hispanic whites in the United States were found in both the Epidemiologic Catchment Area Survey [ECA $]^{[10]}$ and NCS$\mathrm{R}^{[22]}$ samples. Rates of OCD among Hispanics are variable, with NCS-R lifetime rates for Hispanics exceeding non-Hispanic whites and non-Hispanic blacks ${ }^{[22}{ }^{22}$ whereas ECA lifetime rates of OCD among Hispanics are lower than those found for non-Hispanic whites and non-Hispanic blacks. ${ }^{[10]}$
Limited sample sizes of blacks and broad racial coding schemes in previous clinical and epidemiologic studies have not allowed examination of differences in psychopathology between black American subgroups. ${ }^{[23,24]}$ Blacks from the Caribbean make up the largest black ethnic subgroup in the United States. ${ }^{25,26]}$ Recent immigration trends resulted in a $67 \%$ increase in Caribbean black population in the United States during the 1990s. ${ }^{[27]}$ In some large U.S. cities (e.g. New York, Boston, Miami) the proportion of blacks of Caribbean descent meets or exceeds one-quarter of the overall black population. Although heterogeneity within the black population in the United States has largely been ignored, notable differences exist between blacks of Caribbean descent and African Americans with respect to ethnicity, national heritage, and living circumstances. ${ }^{[27]}$ One important difference between African Americans and Caribbean black populations is that Caribbean blacks in the United States are significantly more likely to be first- or second-generation immigrants than is true for other members of the black population. ${ }^{[28]}$ Despite the considerable differences between these groups, the co-categorization of slave-descendent blacks, blacks of more recent African immigration status, and U.S.-born and foreign-born Caribbean blacks as "African Americans" discourages research examining differences in health status and social circumstances between these groups.

In keeping with the research-limiting effects of broadly classifying blacks in America, little is known about the nature of mental illness and associated help seeking among African Americans and blacks of Caribbean descent in the United States. The limited amount of mental health research that does exist comparing these groups indicates that both first- and second-generation Caribbean immigrants experience higher-than-expected rates of schizophrenia ${ }^{[29,30]}$ and mania. ${ }^{[31]}$ Additionally, Caribbean blacks report higher levels of psychological distress compared to African Americans born in the United States. ${ }^{[32]}$ Conversely, rates of depression are similar among African Americans, Caribbean blacks, and non-Hispanic whites in the United States. ${ }^{[33]}$ Although the comparative rates of OCD among African Americans and Caribbean blacks living in the United States have not yet been examined, we hypothesize that higher levels of overall psychological distress among Caribbean blacks may yield higher rates of OCD compared to African Americans. Predicting rates of OCD across cultures, however, is clearly an uncertain endeavor given the variability of prevalence rates found in previous cross-national epidemiologic studies of OCD. ${ }^{[19]}$ 
The importance of OCD prevalence rates notwithstanding, little is known about the nature and impact of OCD among blacks in the United States. Available information regarding mental health disorders among blacks suggests that mental illness is especially persistent in this group. ${ }^{[33,34]}$ Although OCD is known to be very persistent in general population samples, ${ }^{[16]}$ its relative persistence rates across cultural groups in the United States is unclear. In the ECA study, blacks meeting lifetime OCD criteria were more likely than non-Hispanic whites or Hispanics to also meet criteria for 12-month OCD, suggesting that OCD may be particularly persistent among blacks. ${ }^{[35]}$ Mental illness severity is another important variable of interest related to understanding the nature of mental illness that has also not been sufficiently investigated with respect to race/ethnicity. ${ }^{[36]}$ Although little is known about the severity of mental illness among blacks with OCD, access barriers to quality mental health treatment may lead one to hypothesize that blacks with OCD experience high levels of illness severity. Similarly, little research is available regarding help-seeking behavior among black Americans with OCD, although recent data from an anxiety disorders screening event suggest that very few blacks with OCD (6.3\%) seek treatment for their condition. ${ }^{[37]}$ Finally, no information regarding the nature of OCD and associated help-seeking behavior comparing African Americans and blacks of Caribbean descent is available. Overall, gathering information about the persistence, clinical severity, and service use among African Americans and blacks of Caribbean descent with OCD in the United States is imperative in order to appropriately assess the care needs of these important groups.

Beyond the need to address these important gaps in the current literature regarding African American and Caribbean blacks with OCD in the United States, it is also important to disseminate the most up-to-date information about OCD among these groups. Psychopathology is clearly influenced by social and economic hardships. ${ }^{[38,39]}$ Recent economic declines have been associated with growing disparities in economic status among black Americans, making contemporary assessment of psychopathology among black Americans especially relevant.

The purpose of this paper is to examine the prevalence and impact of OCD on blacks in America using the National Survey of American Life[NSAL], ${ }^{[40]}$ a recently completed epidemiologic study of the mental health of black Americans and non-Hispanic whites in the United States. This is the first comprehensive examination of OCD among African Americans and blacks of Caribbean descent. In this study, the prevalence and persistence of OCD will be reported along with data on psychiatric comorbidity, mental illness severity, functional impairment, service use, and the socio-demographic correlates of OCD.

\section{METHODS}

\section{SAMPLE}

The NSAL is a comprehensive study of the mental health of African Americans and blacks of Caribbean descent. ${ }^{[25]}$ The NSAL adult study is an integrated national multi-stage household probability sample of 3,570 African Americans, 1,621 blacks of Caribbean descent (Caribbean blacks) and 891 non-Hispanic whites. Respondents were drawn from a noninstitutionalized civilian population from the coterminous 48 states. One adult (18 years or over) per household was randomly selected to be interviewed. Interviews were conducted from February 2001 to March 2003. The AfricanAmerican participants were selected from geographic segments in proportion to the African American population; the Caribbean black sample was selected from the African-American segments and from metropolitan segments with more than $10 \%$ blacks of Caribbean descent. Respondents were asked to self-identify their race. Those who declared their race to be black and of West Indian or Caribbean descent, or reported that they were from a list of Caribbean countries provided by the interviewer, were coded as Caribbean black. The response rates for the African-American and Caribbean samples were $70.7 \%$ and $77.7 \%$, respectively. Analysis weights were developed for the NSAL to adjust for potential nonresponse bias, to correct for disproportionate sampling, and to ensure population representation across various socio-demographic characteristics. ${ }^{[41]}$ Analyses applying these weights produce statistics nationally representative of the populations of interest. In the NSAL, due to time and cost restraints, OCD was assessed in the African-American and Caribbean black subsamples but not among non-Hispanic white participants.

\section{MEASURES}

Diagnostic assessment. In the NSAL, diagnostic assessment was conducted using the Diagnostic and Statistical Manual (DSM-IV) World Mental Health Composite International Diagnostic Interview [WMH-CIDI]. ${ }^{[42]}$ The WMH-CIDI is a structured, lay interviewer-administered diagnostic interview. The CIDI short-form version (CIDI-SF) Obsessive-Compulsive Disorder diagnostic mod$\mathrm{ule}^{[43]}$ was administered rather than the full WMH-CIDI OCD module. A CIDI-SF OCD diagnosis should be considered a probable DSM-IV OCD diagnosis, since the section does not fully assess DSM-IV criteria. Specifically, persons with a positive CIDI-SF OCD are estimated to have an $84.21 \%$ chance of also being a full CIDI OCD according to the CIDI-SF OCD scoring guidelines. All of the other 12 adult disorders were assessed using the WMH-CIDI. These include panic disorder, agoraphobia, social phobia, generalized anxiety disorder, posttraumatic stress disorder, major depressive disorder, dysthymia, bipolar I \& II disorders, and drug and/or alcohol abuse/dependence.

Socio-demographic correlates. Socio-demographic variables assessed included sex, age, employment status, education, marital status, region of the, ${ }^{[44]}$ U.S. Department of Agriculture. "Other urban" includes areas with populations greater than or equal to 2,500 people and "rural" includes persons living in areas with less than 2,500 people. Region is coded according to The Bureau of Census' Department of Labor regional classification method. ${ }^{[45]}$

Functional impairment. Functional impairment was measured using the World Health Organization's Disability Assessment Schedule II [WHO-DAS-II]. ${ }^{[46]}$ The WHO-DAS-II is based on the International Classification of Functioning, Disability and Health and is cross-culturally applicable. The WHO-DAS-II was not administered to respondents who reported that their overall physical and mental health was excellent. The WHO-DAS-II measures 30day functional impairment (number of days in the preceding 30 with 
impairment) in seven domains: days out of role (unable to carry out normal activities); self-care (washing, grooming, etc.); mobility (standing, moving, etc.); cognition (concentration, memory, etc.); social (conversing, maintaining friendships, etc.); productivity (quality and quantity of daily activities at home and work); and family burden (respondent interference with the life and activities of close friends and family). For days out of role, the score is the number of days that respondents were completely unable to carry out their normal activities. For the other domains, the impairment score is the number of days that the respondents' symptoms caused difficulty in the given area of functioning weighted by the level of difficulty. WHO-DAS-II functional impairment scores are not limited to impairment resulting from OCD.

Overall mental illness severity. Respondents who met the 12-month criteria for OCD or any other mental disorder were assigned to one of three severity categories: severe, moderate, or mild. Severe cases met at least one of the following conditions: was diagnosed or ever treated for psychosis; met criteria for bipolar I or II disorder; reported a serious suicide attempt within the past year; scored 50 or below on the Global Assessment of Functioning ${ }^{[1]}$ scale; met current criteria for substance dependence with associated severe role impairment; or scored in a range from 7 to 10 on the Sheehan Disability Scale. ${ }^{[47]}$ Cases classified as moderate met at least one of the following conditions: had suicidal ideation, a gesture, or plan; a Global Assessment of Functioning score between 51 and 60; substance dependence without associated severe role impairment; or moderate role impairment associated with any current mental disorder. All other cases were classified as mild. OCD-specific severity was not assessed in the NSAL.

Service use. Service use for emotions, nerves, mental health, or use of alcohol or drugs within the last 12 months was categorized into several service sectors. The health services sector includes two provider sub-groups: specialty mental health (psychiatrists, psychologists, counselors, social workers, other mental health professionals, mental health hotlines) and general medical sectors (general practitioners, family doctors, nurses, occupational therapists, other health professionals). The nonhealth care sector also includes two subgroups: human service (religious and spiritual advisors, counselors and social workers seen in nonmental health settings) and complementary-alternative sectors (herbalists, chiropractors, spiritualists, self-help groups, internet support groups). Participants were included in the "any services" category if they consulted at least one of the above providers in the past 12 months.

Given that pharmacological treatment of OCD primarily utilizes serotonin reuptake inhibiting medications [SRIs], ${ }^{[48]}$ a service utilization variable was created that captured the use of any SRI medication (citalopram, clomipramine, fluoxetine, fluvoxamine, paroxetine, sertraline) in the past 12 months.

\section{ANALYSIS STRATEGY}

All analyses were weighted to be nationally representative of the populations of interest and were conducted using the SAS 9.1.3 software package. ${ }^{[49]}$ Because the NSAL used a multi-stage sample design, involving both clustering and stratification, specialized statistical techniques (Taylor series expansion method) were utilized to account for the complexity of the design and its associated standard errors where appropriate. Bivariate cross-tabulations were used to calculate all proportions. Unweighted frequencies but weighted percentages are reported. The Rao-Scott $\chi^{2}$ statistic, a complex design-corrected measure of association, was used to test for associations across categorical variables. Odds ratios were obtained by exponentiating the coefficients calculated in bivariate logistic regression models.
Standard errors adjusted for complex designs are usually larger than nonadjusted standard errors. Furthermore, the NSAL Caribbean black sample is significantly more clustered than the AfricanAmerican sample. For this reason, the standard errors for the Caribbean black sample will usually be higher than those for the African-American sample when correctly estimated. Therefore, many comparisons may show large differences, yet are not statistically significant.

\section{RESULTS}

\section{SAMPLE CHARACTERISTICS}

Table 1 displays the socio-demographic characteristics of all African-American and Caribbean black NSAL participants. Caribbean blacks were more likely to be married, reside in the Northeast and major metropolitan areas, and to report higher levels of education and income compared to African Americans.

\section{PREVALENCE AND PERSISTENCE}

The lifetime prevalence rate of OCD for the combined African-American and Caribbean black populations was $1.63 \%$. The 12 -month rate was $1.49 \%$ (see Table 2). There were no significant differences in the lifetime or 12-month rates of OCD between the African-American and Caribbean black groups. Table 2 also reveals very similar lifetime and 12 -month rates of OCD among males $(1.7 \%)$ and females $(1.6 \%)$. Nearly $92 \%$ of respondents with lifetime OCD met criteria for 12-month OCD. OCD was significantly more persistent $\left(\chi^{2}=4.93 ; P=.03\right)$ among females (95\%) compared to males (88\%). There were no significant differences in OCD persistence rates between the African-American and Caribbean black sub-groups.

\section{AGE OF ONSET}

Table 3 presents mean age of onset of OCD, obsessions, and compulsions for the total sample of respondents with OCD and for the African-American (OCD onset $=31.8$ years) and Caribbean black subsamples (OCD onset $=29.8$ years). No significant differences in OCD, compulsion, or obsession onset age were observed.

\section{COMORBIDITY}

Table 4 reveals that a striking majority of African Americans (93.2\%) and Caribbean blacks (95.6\%) with OCD met the diagnostic criteria for at least one other lifetime psychiatric disorder. Major depressive disorder (44\%), posttraumatic stress disorder (44\%), social phobia (45\%), panic disorder (25\%), and generalized anxiety disorder (24\%) were highly prevalent in both groups. Caribbean blacks with OCD were significantly more likely to meet criteria for panic disorder compared to African Americans (61versus 21\% respectively). 
TABLE 1. Sociodemographic weighted distribution of the National Survey of American Life sample compared by race

\begin{tabular}{|c|c|c|c|c|}
\hline \multirow[b]{2}{*}{ Characteristic } & \multicolumn{2}{|c|}{$\begin{array}{c}\text { African } \\
\text { American } \\
(N=3570)\end{array}$} & \multicolumn{2}{|c|}{$\begin{array}{c}\text { Caribbean black } \\
\qquad(N=1621)\end{array}$} \\
\hline & $n$ & $\%$ & $n$ & $\%$ \\
\hline \multicolumn{5}{|l|}{ Age } \\
\hline $18-29$ & 807 & 24.4 & 434 & 31.3 \\
\hline $30-44$ & 1272 & 35.4 & 603 & 33.7 \\
\hline $45-59$ & 860 & 23.9 & 360 & 20.1 \\
\hline$\geq 60$ & 631 & 16.3 & 224 & 14.9 \\
\hline \multicolumn{5}{|l|}{ Sex } \\
\hline Male & 1271 & 44.1 & 643 & 51.1 \\
\hline Female & 2299 & 55.9 & 978 & 48.9 \\
\hline \multicolumn{5}{|l|}{ Work status } \\
\hline Employed & 2333 & 66.9 & 1182 & 75.4 \\
\hline Unemployed & 366 & 10.1 & 158 & 8.8 \\
\hline Not in labor force & 861 & 23.1 & 279 & 15.9 \\
\hline \multicolumn{5}{|l|}{ Education } \\
\hline $0-11$ years & 909 & 24.3 & 299 & 21.2 \\
\hline 12 & 1344 & 37.7 & 477 & 29.7 \\
\hline $13-15$ & 799 & 23.9 & 438 & 25.9 \\
\hline$\geq 16$ & 471 & 14.1 & 388 & 23.2 \\
\hline \multicolumn{5}{|l|}{ Income } \\
\hline $0-17,999$ & 1308 & 31 & 368 & 21.1 \\
\hline $18,000-31,999$ & 912 & 25.1 & 434 & 25.4 \\
\hline $32,000-54,999$ & 765 & 23.5 & 384 & 21.9 \\
\hline$\geq 55,000$ & 541 & 20.4 & 421 & 31.6 \\
\hline \multicolumn{5}{|l|}{ Marital status } \\
\hline Married/cohabitating & 1220 & 41.6 & 690 & 49.8 \\
\hline Divorced/separated/widowed & 1163 & 26.8 & 384 & 18.8 \\
\hline Never married & 1170 & 31.6 & 542 & 31.3 \\
\hline \multicolumn{5}{|l|}{ Foreign born } \\
\hline Born in the US & 3464 & 97.7 & 440 & 35.1 \\
\hline Born outside the US & 64 & 2.3 & 1166 & 64.9 \\
\hline \multicolumn{5}{|l|}{ Region } \\
\hline Northeast & 411 & 15.7 & 1135 & 55.8 \\
\hline Midwest & 684 & 20.6 & 13 & 4.2 \\
\hline South & 2241 & 54.5 & 455 & 28.7 \\
\hline West & 234 & 9.3 & 18 & 11.4 \\
\hline \multicolumn{5}{|l|}{ Urbanicity } \\
\hline Major metropolitan & 3105 & 88.9 & 1621 & 100 \\
\hline Other urban & 312 & 7.5 & & \\
\hline Rural & 153 & 3.7 & & \\
\hline
\end{tabular}

Reported $n$ represent the unweighted sample sizes. All reported percentages are weighted to be nationally representative of the given population and subpopulations in the coterminous 48 states of the United States.

NSAL, National Survey of American Life.

\section{SOCIODEMOGRAPHIC CORRELATES}

Table 5 presents odds ratios for OCD risk. Analyses involving the combined OCD sample revealed statistically significant $(P \leq .05)$ elevations of lifetime and 12month OCD among those who were in the younger three age cohorts compared to those over 60 years of age. Respondents who were unemployed, reported lower incomes, or had fewer years of formal schooling had significantly increased odds of having lifetime and 12-month OCD.

The associations of low income, low employment, less education, and a younger age with increased risk of OCD were preserved in the African-American and Caribbean sub-samples when analyzed separately. Ever being married (either currently married or divorced) was associated with reduced lifetime risk of OCD at a marginal level of significance in the total sample. This trend was primarily due to a statistically significant preponderance of Caribbean blacks with OCD who had never been married.

\section{FUNCTIONAL IMPAIRMENT}

The combined 12-month OCD sample reported significantly greater impairment on the days out of role, productivity, cognition, mobility, self-care, social, and family burden subscales of the WHO-DAS-II compared to a pooled group of NSAL participants meeting criteria for any of the twelve 12-month adult DSM disorders other than OCD (African-American and Caribbean black participants only;see Table 6). Caribbean blacks with OCD experienced significantly greater impairment in the cognitive, self-care, and social dimension of the WHO-DAS-II compared to African Americans with OCD.

\section{SEVERITY OF MENTAL ILLNESS}

The large majority of respondents with 12 -month OCD was found to have either moderate $(40 \%)$ or severe $(46 \%)$ overall mental illness (see Table 7 ). There were no significant differences in overall mental illness severity between the African-American and Caribbean black groups. As indicated earlier, OCD-specific severity was not assessed in this study. Table 8 provides severity data comparing OCD to several other disorders assessed in the NSAL (African-American and Caribbean black participants only). $\chi^{2}$ analysis comparing persons with OCD to a pooled group of NSAL participants with any of the 12 adult DSM disorders other than OCD revealed that persons with OCD experienced significantly more severe overall mental illness. Table 8 also presents information on mental illness severity for specific 12-month mood and anxiety disorders. Although comorbidity and sample size issues preclude meaningful statistical comparisons between OCD and other specific anxiety and mood disorders, persons with OCD experienced more severe overall mental illness compared to any of the other disorders presented in Table 8.

\section{USE OF SERVICES}

Among all persons with 12-month OCD, only 41\% used any of the assessed services within the previous 12 months (Table 9). Only 20\% of persons with OCD received services from a specialty mental health setting. 
TABLE 2. Prevalence of DSM-IV/WMH-CIDI for OCD in the NSAL sample by race and gender

\begin{tabular}{|c|c|c|c|c|c|c|c|c|c|c|}
\hline & \multicolumn{5}{|c|}{ Lifetime } & \multicolumn{5}{|c|}{12 Months among lifetime } \\
\hline & $N$ & $\%$ & SE (\%) & $\chi^{2}$ & $P$-value & $N$ & $\%$ & $S E(\%)$ & $\chi^{2}$ & $P$-value \\
\hline \multicolumn{11}{|l|}{ Race/ethnicity } \\
\hline African Americans $(n=3,417)$ & 54 & 1.6 & 0.3 & 0.2 & 0.70 & 49 & 1.5 & 0.3 & 0.2 & 0.66 \\
\hline Caribbean blacks $(n=1,578)$ & 23 & 2.0 & 0.8 & & & 21 & 1.8 & 0.8 & & \\
\hline Total $(N=4,995)$ & 77 & 1.6 & 0.3 & & & 70 & 1.5 & 0.2 & & \\
\hline \multicolumn{11}{|l|}{ Gender } \\
\hline Male $(n=1,840)$ & 32 & 1.7 & 0.4 & 0.0 & 0.80 & 27 & 1.5 & 0.4 & 0.0 & 0.94 \\
\hline Female $(n=3,155)$ & 45 & 1.6 & 0.3 & & & 43 & 1.5 & 0.3 & & \\
\hline Total $(N=4,995)$ & 77 & 1.6 & 0.3 & & & 70 & 1.5 & 0.2 & & \\
\hline
\end{tabular}

Reported $n$ represent unweighted frequencies. All prevalence estimates are weighted to be nationally representative of the given population and subpopulations in the coterminous 48 states of the United States. Standard errors and $\chi^{2}$ statistics are adjusted for the sampling stratification, clustering, and weighting of the data.

SE, standard error; WMH-CIDI, World Mental Health Composite International Diagnostic Interview; OCD, obsessive-compulsive disorder; NSAL, National Survey of American Life.

TABLE 3. Age of onset (years) of lifetime OCD diagnosis, compulsions, and obsessions

\begin{tabular}{|c|c|c|c|c|c|c|c|c|c|c|c|c|c|c|}
\hline \multirow[b]{2}{*}{ Variables } & \multicolumn{4}{|c|}{ Total OCD sample } & \multicolumn{4}{|c|}{ African Americans } & \multicolumn{4}{|c|}{ Caribbean blacks } & \multicolumn{2}{|c|}{ Race differences } \\
\hline & $n$ & Mean & $95 \% \mathrm{C}$ & L for mean & $n$ & Mean & $95 \% \mathrm{Cl}$ & or mean & $n$ & Mean & $95 \% \mathrm{C}$ & CL for mean & $t$-value & $P$-value \\
\hline OCD Diagnosis & 75 & 31.6 & 27.3 & 35.9 & 52 & 31.8 & 27.2 & 36.4 & 23 & 29.8 & 16.7 & 42.9 & .3 & .74 \\
\hline Compulsions & 60 & 33.8 & 29.2 & 38.4 & 43 & 34.0 & 29.0 & 38.9 & 17 & 32.0 & 18.9 & 45.2 & .3 & .77 \\
\hline Obsessions & 73 & 33.9 & 29.7 & 38.1 & 52 & 34.1 & 29.6 & 38.6 & 21 & 31.7 & 19.7 & 43.6 & .4 & .69 \\
\hline
\end{tabular}

Reported $n$ represent unweighted frequencies. All mean estimates are weighted to be nationally representative of the given population and subpopulations in the coterminous 48 states of the United tates.S Confidence limits and $t$-statistics are adjusted for the sampling stratification, clustering, and weighting of the data. All $t$-tests were two-sided.

OCD, obsessive-compulsive disorder; CL, confidence limit.

Similarly, approximately $20 \%$ of persons with 12 month OCD reported using SRI medications over the past year. No significant differences were found in the use of specialty mental health service or SRI medications between the African-American and Caribbean black sub-samples although there was a trend toward African Americans using SRIs at a greater rate than Caribbean blacks. There was one notable difference between Caribbean blacks and African Americans wherein no Caribbean blacks reported using the human services sector.

For the combined Caribbean black and AfricanAmerican OCD sample, significantly greater 12 -month service use was observed in almost all sectors as overall mental illness severity increased (Table 10). Nearly $60 \%$ of OCD respondents with severe mental illness sought services from any sector compared to less than $4 \%$ of those with overall mild illness. Nearly $40 \%$ of OCD respondents with severe mental illness used specialty mental health services within the past year compared to $0 \%$ of persons with mild mental illness. Low statistical power precluded any meaningful analysis of the relationship between mental illness severity and service use stratified according to ethnicity.

\section{DISCUSSION}

The results of this study document the substantial impact of OCD on the black population of the United States. In the black community in the United States, OCD is prevalent, is commonly associated with other psychiatric disorders, substantially affects vocational and social life, and is associated with strikingly high levels of overall mental health impairment.

The 12-month and lifetime rates of OCD for the combined sample of African Americans and Caribbean blacks were almost identical to the rates of OCD $\left(1.6 \%\right.$; all races combined) found in the NCS-R. ${ }^{[16]}$ Lifetime and 12-month rates of OCD did not significantly differ between African Americans and blacks of Caribbean descent. This result is somewhat surprising given considerable cross-cultural variations in OCD rates observed in other studies. ${ }^{[19]}$ Overall, these findings strongly indicate that the important cultural differences between African Americans and Caribbean blacks do not significantly influence their risk for developing OCD. A similar concordant rate between African Americans and Caribbean blacks was also recently observed for major depression using the NSAL sample. ${ }^{[33]}$ The prevalence rates of OCD 
TABLE 4. Comorbidity of CIDI/DSM-IV OCD with other NSAL disorders by race

\begin{tabular}{|c|c|c|c|c|c|c|c|c|c|c|c|}
\hline & \multicolumn{3}{|c|}{ Total OCD sample } & \multicolumn{3}{|c|}{ African Americans } & \multicolumn{3}{|c|}{ Caribbean blacks } & \multicolumn{2}{|c|}{ Race differences } \\
\hline & Freq & $\begin{array}{c}\text { Row } \\
(\%)\end{array}$ & $\begin{array}{l}\text { Std. error } \\
\quad(\%)\end{array}$ & Freq & $\begin{array}{l}\text { Row } \\
(\%)\end{array}$ & $\begin{array}{l}\text { Std. error } \\
(\%)\end{array}$ & Freq & $\begin{array}{l}\text { Row } \\
(\%)\end{array}$ & $\begin{array}{l}\text { Std. error } \\
(\%)\end{array}$ & $\chi^{2}$ & $P$-value \\
\hline Lifetime anxiety disorder other than OCD & & & & & & & & & & 1.6 & 0.21 \\
\hline No & 17 & 16.2 & 4.5 & 12 & 16.1 & 4.8 & 5 & 17.4 & 10.5 & & \\
\hline Yes & 60 & 83.8 & 4.5 & 42 & 83.9 & 4.8 & 18 & 82.6 & 10.5 & & \\
\hline Lifetime panic disorder & & & & & & & & & & 5.9 & 0.02 \\
\hline No & 57 & 75.2 & 6.2 & 40 & 78.5 & 5.9 & 17 & 39.0 & 19.0 & & \\
\hline Yes & 20 & 24.8 & 6.2 & 14 & 21.5 & 5.9 & 6 & 61.0 & 19.0 & & \\
\hline Lifetime agoraphobia without panic & & & & & & & & & & 3.0 & 0.08 \\
\hline No & 63 & 80.9 & 5.9 & 43 & 79.7 & 6.3 & 20 & 94.2 & 4.4 & & \\
\hline Yes & 14 & 19.1 & 5.9 & 11 & 20.3 & 6.3 & 3 & 5.8 & 4.4 & & \\
\hline Lifetime social phobia & & & & & & & & & & 0.9 & 0.30 \\
\hline No & 45 & 54.9 & 7.5 & 31 & 56.5 & 7.8 & 14 & 37.2 & 18.6 & & \\
\hline Yes & 32 & 45.1 & 7.5 & 23 & 43.5 & 7.8 & 9 & 62.8 & 18.6 & & \\
\hline Lifetime general anxiety & & & & & & & & & & 0.3 & 0.90 \\
\hline No & 59 & 76.0 & 6.7 & 43 & 75.8 & 7.2 & 16 & 78.5 & 13.0 & & \\
\hline Yes & 18 & 24.0 & 6.7 & 11 & 24.2 & 7.2 & 7 & 21.5 & 13.0 & & \\
\hline Lifetime posttraumatic stress & & & & & & & & & & 2.6 & 0.11 \\
\hline No & 44 & 56.4 & 7.5 & 33 & 58.8 & 7.8 & 11 & 30.4 & 15.6 & & \\
\hline Yes & 33 & 43.6 & 7.5 & 21 & 41.2 & 7.8 & 12 & 69.6 & 15.6 & & \\
\hline Any lifetime mood disorder & & & & & & & & & & 1.6 & 0.21 \\
\hline No & 36 & 47.8 & 7.5 & 22 & 45.8 & 7.9 & 14 & 69.5 & 16.3 & & \\
\hline Yes & 41 & 52.2 & 7.5 & 32 & 54.2 & 7.9 & 9 & 30.5 & 16.3 & & \\
\hline DSM-major depression & & & & & & & & & & 0.6 & 0.40 \\
\hline No & 44 & 55.8 & 7.5 & 30 & 54.5 & 7.9 & 14 & 69.5 & 16.3 & & \\
\hline Yes & 33 & 44.2 & 7.5 & 24 & 45.5 & 7.9 & 9 & 30.5 & 16.3 & & \\
\hline Lifetime eating disorder & & & & & & & & & & 0.9 & 0.30 \\
\hline No & 59 & 73.9 & 6.4 & 39 & 72.7 & 6.9 & 20 & 86.3 & 10.4 & & \\
\hline Yes & 18 & 26.1 & 6.4 & 15 & 27.3 & 6.9 & 3 & 13.7 & 10.4 & & \\
\hline Lifetime substance disorder & & & & & & & & & & 2.4 & 0.13 \\
\hline No & 59 & 71.7 & 7.0 & 41 & 74.2 & 7.0 & 18 & 43.8 & 21.2 & & \\
\hline Yes & 18 & 28.3 & 7.0 & 13 & 25.8 & 7.0 & 5 & 56.2 & 21.2 & & \\
\hline Lifetime social phobia & & & & & & & & & & 0.9 & 0.30 \\
\hline No & 45 & 54.9 & 7.5 & 31 & 56.5 & 7.8 & 14 & 37.2 & 18.6 & & \\
\hline Yes & 32 & 45.1 & 7.5 & 23 & 43.5 & 7.8 & 9 & 62.8 & 18.6 & & \\
\hline $\begin{array}{l}\text { Lifetime disorder usually diagnosed } \\
\text { in infancy, childhood, adolescence }\end{array}$ & & & & & & & & & & 1.9 & 0.20 \\
\hline No & 17 & 24.0 & 6.9 & 11 & 25.7 & 7.7 & 6 & 10.5 & 7.0 & & \\
\hline Yes & 35 & 76.0 & 6.9 & 24 & 74.3 & 7.7 & 11 & 89.5 & 7.0 & & \\
\hline Any lifetime disorder other than OCD & & & & & & & & & & 0.2 & 0.60 \\
\hline No & 7 & 6.6 & 3.0 & 5 & 6.8 & 3.2 & 2 & 4.4 & 3.7 & & \\
\hline Yes & 70 & 93.4 & 3.0 & 49 & 93.2 & 3.2 & 21 & 95.6 & 3.7 & & \\
\hline
\end{tabular}

Reported frequencies are unweighted. All prevalence estimates are weighted to be nationally representative of the given population and subpopulations in the coterminous 48 states of the United States. Standard errors and $\chi^{2}$ statistics are adjusted for the sampling stratification, clustering, and weighting of the data.

All $\chi^{2}$ significance tests based on one degree of freedom.

CIDI, Composite International Diagnostic Interview; OCD, obsessive-compulsive disorder; NSAL, National Survey of American Life.

in the present study differ from rates of OCD found in the ECA study [whites (2.62\%), African Americans (2.31\%), Hispanics $(1.82 \%)]{ }^{[10]}$ The higher prevalence of OCD in the ECA may be due to several factors including differing sampling strategies and/or OCD diagnostic criteria.

Lifetime and 12-month prevalence rates of OCD were strikingly similar, indicating that OCD is an extraordinarily persistent disorder among blacks in the United States. The persistence of OCD in the NSAL sample is substantially greater than that found in the National Comorbidity Survey ${ }^{[16]}$ suggesting that once blacks meet criteria for OCD, they are particularly unlikely to experience a remission. High levels of overall mental illness comorbidity and severity, limited access to state-of-the-art treatments, or reduced responses to currently available OCD treatments, which have not been well tested in the AfricanAmerican population may all contribute to high OCD persistence observed in these groups. 
TABLE 5. Bivariate odds ratios for lifetime and 12 month OCD risk by race

\begin{tabular}{|c|c|c|c|c|c|c|}
\hline \multirow[b]{2}{*}{ Correlates } & \multicolumn{2}{|c|}{ Total sample } & \multicolumn{2}{|c|}{ African Americans } & \multicolumn{2}{|c|}{ Caribbean blacks } \\
\hline & $\begin{array}{l}\text { Lifetime } \\
(n=4,995)\end{array}$ & $\begin{array}{l}12 \text { months } \\
(n=4,995)\end{array}$ & $\begin{array}{c}\text { Lifetime } \\
(n=3,417)\end{array}$ & $\begin{array}{l}12 \text { months } \\
(n=3,417)\end{array}$ & $\begin{array}{c}\text { Lifetime } \\
(n=1,578)\end{array}$ & $\begin{array}{l}12 \text { months } \\
(n=1,578)\end{array}$ \\
\hline \multicolumn{7}{|l|}{ Age } \\
\hline $18-29$ & $6.0(1.8-20.0)$ & $10.1(2.3-44.7)$ & $5.6(1.7-18.9)$ & $9.3(2.4-36.5)$ & NA & NA \\
\hline $30-44$ & $4.3(1.1-16.9)$ & $7.5(1.7-33.7)$ & $3.8(.9-15.2)$ & $6.6(1.3-33.9)$ & NA & NA \\
\hline $45-59$ & $5.2(1.4-19.7)$ & $9.6(2.1-43.5)$ & $5.0(1.3-19.1)$ & $9.3(1.7-49.9)$ & NA & NA \\
\hline \multirow[t]{2}{*}{$\geq 60$} & 1.0 & 1.0 & 1.0 & 1.0 & NA & NA \\
\hline & $\chi^{2}=9.0, P=.03$ & $\chi^{2}=9.7, P=.02$ & $\chi^{2}(3)=8.4, P=.04$ & $\chi^{2}=10.8, P=.01$ & NA & NA \\
\hline \multicolumn{7}{|l|}{ Sex } \\
\hline Male & $1.1(.6-1.9)$ & $1.0(.5-1.8)$ & $1.0(.535-1.783)$ & $.9(.5-1.8)$ & $2.8(.6-12.1)$ & $2.5(.5-12.1)$ \\
\hline Female & $\chi^{2}=.4, P=.80$ & $\begin{array}{c}1.0 \\
\chi^{2}=.0, P=.90\end{array}$ & $\begin{array}{c}1.0 \\
\chi^{2}=.01, P=.94\end{array}$ & $\begin{array}{c}1.0 \\
\chi^{2}=.11, P=.74\end{array}$ & $\begin{array}{c}1.0 \\
\chi^{2}=1.8, P=.18\end{array}$ & $\begin{array}{c}1.0 \\
\chi^{2}=1.3, P=.30\end{array}$ \\
\hline \multicolumn{7}{|l|}{ Employment status } \\
\hline Employed & 1.0 & 1.0 & 1.0 & 1.0 & 1.0 & 1.0 \\
\hline Unemployed & $2.9(1.3-6.6)$ & $3.0(1.3-6.7)$ & $2.8(1.2-6.7)$ & $2.9(1.1-7.4)$ & $4.9(1.6-14.9)$ & $5.2(1.8-15.2)$ \\
\hline \multirow[t]{2}{*}{ Not in labor force } & $2.3(1.2-4.4)$ & $2.3(1.1-4.6)$ & $1.9(1.0-3.9)$ & $1.9(1.0-3.9)$ & $17.4(4.0-76.4)$ & $17.0(3.5-82.3)$ \\
\hline & $\chi^{2}=11.3, P=.04$ & $\chi^{2}=8.8, P=.01$ & $\chi^{2}=8.4, P=.02$ & $\chi^{2}=7.7, P=.02$ & $\chi^{2}=20.7, P<.01$ & $\chi^{2}=20.8, P<.01$ \\
\hline \multicolumn{7}{|l|}{ Education } \\
\hline Less than HS & $10.2(2.9-36.3)$ & $62.8(17.6-224.5)$ & $10.3(2.3-45.0)$ & $\mathrm{NA}$ & $13.1(2.2-79.8)$ & $13.1(2.2-79.8)$ \\
\hline HS grad & $7.5(2.2-25.5)$ & $41.6(11.6-149.0)$ & $8.1(2.0-33.8)$ & NA & $3.9(0.9-17.3)$ & $3.1(0.6-15.0)$ \\
\hline Some college & $2.8(0.6-12.1)$ & $14.7(3.2-67.5)$ & $2.9(0.5-15.8)$ & NA & $2.5(0.7-8.5)$ & $2.3(0.6-7.9)$ \\
\hline \multirow{2}{*}{$\begin{array}{l}\text { College grad } \\
\text { or more }\end{array}$} & 1.0 & 1.0 & 1.0 & NA & 1.0 & 1.0 \\
\hline & $\chi^{2}=20.6, P=.01$ & $\chi^{2}=44.3, P<.01$ & $\chi^{2}=16.0, P=.01$ & NA & $\chi^{2}=8.7, P=.03$ & $\chi^{2}=8.3, P=.04$ \\
\hline \multicolumn{7}{|l|}{ Marital status } \\
\hline Married/Partner & $.5(.2-1.2)$ & $.5(.2-1.0)$ & $.6(.3-1.1)$ & $.5(.3-1.1)$ & $.2(.04-.6)$ & $.1(.03-.4)$ \\
\hline $\begin{array}{l}\text { Divorced/ } \\
\text { separated/widowed }\end{array}$ & $0.5(0.3-1.0)$ & $0.5(0.2-1.0)$ & $0.6(0.3-1.4)$ & $0.5(0.2-1.3)$ & $0.1(0.01-0.4)$ & $0.1(0.1-0.5)$ \\
\hline Never married & $\begin{array}{c}1.0 \\
\chi^{2}=5.7, P=0.06\end{array}$ & $\begin{array}{c}1.0 \\
\chi^{2}=6.0, P=0.05\end{array}$ & $\begin{array}{c}1.0 \\
\chi^{2}=3.4, P=0.20\end{array}$ & $\begin{array}{c}1.0 \\
\chi^{2}=4.2, P=0.10\end{array}$ & $\begin{array}{c}1.0 \\
\chi^{2}=10.3, P<0.01\end{array}$ & $\begin{array}{c}1.0 \\
\chi^{2}=12.1, P=0.02\end{array}$ \\
\hline \multicolumn{7}{|c|}{ 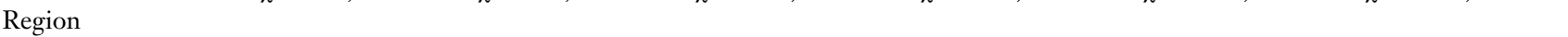 } \\
\hline Northeast & $1.8(0.8-3.7)$ & $1.9(0.8-4.2)$ & $1.8(0.8-4.3)$ & $2.0(0.9-4.7)$ & $2.5(0.3-17.4)$ & $2.1(0.3-14.9)$ \\
\hline Midwest & $2.0(0.9-4.3)$ & $2.3(1.1-4.8)$ & $1.7(0.8-3.8)$ & $1.9(0.9-4.4)$ & $43.0(3.1-595.3)$ & $43.0(3.1-595.3)$ \\
\hline South & 1.0 & 1.0 & 1.0 & 1.0 & 1.0 & 1.0 \\
\hline \multirow[t]{2}{*}{ West } & $1.0(0.3-3.8)$ & $1.0(0.2-4.1)$ & $1.1(0.3-4.1)$ & $1.0(0.2-4.7)$ & NA & NA \\
\hline & $\chi^{2}=4.2, P=0.20$ & $\chi^{2}=5.9, P=0.10$ & $\chi^{2}=2.9, P=0.40$ & $\chi^{2}=4.1, P=0.26$ & $\chi^{2}=838.0, P<.01$ & $\chi^{2}=809.0, P<.01$ \\
\hline \multicolumn{7}{|l|}{ Income categories } \\
\hline $\begin{array}{l}\text { Poverty } \\
\text { line or lower }\end{array}$ & $4.4(1.0-18.7)$ & $26.6(6.1-115.7)$ & $5.6(0.7-42.3)$ & NA & $2.0(0.4-9.4)$ & $5.1(0.6-45.7)$ \\
\hline $\begin{array}{l}1 \times \text { to } 3 \times \\
\text { Poverty line }\end{array}$ & $4.1(1.0-17.4)$ & $24.7(5.7-107.0)$ & $5.1(0.7-36.8)$ & NA & $2.5(0.3-19.6)$ & $5.1(0.6-45.7)$ \\
\hline $\begin{array}{l}3 \times \text { to } 6 \times \\
\text { Poverty line }\end{array}$ & $1.1(0.2-5.6)$ & $6.5(1.2-34.1)$ & $1.5(0.2-12.6)$ & NA & $0.4(0.1-1.9)$ & $0.8(0.1-4.5)$ \\
\hline \multirow[t]{2}{*}{$6 \times$ poverty line } & 1.0 & 1.0 & 1.0 & NA & 1.0 & 1.0 \\
\hline & $\chi^{2}=13.3, P=0.04$ & $\chi^{2}=26.0, P<.01$ & $\chi^{2}=11.0, P=0.01$ & NA & $\chi^{2}=8.9, P=0.03$ & $\chi^{2}=9.8, P=0.02$ \\
\hline \multicolumn{7}{|c|}{$\pi$} \\
\hline Major metro & $1.5(0.3-8.4)$ & $1.4(0.3-5.9)$ & $1.4(0.3-8.3)$ & $1.3(0.2-7.7)$ & All major metro & All major metro \\
\hline Other urban & $1.5(0.4-5.9)$ & $1.2(0.2-6.7)$ & $1.5(0.4-5.9)$ & $1.177(0.2-5.8)$ & & \\
\hline Rural & $\begin{array}{c}1.0 \\
\chi^{2}=0.4, P=.90\end{array}$ & $\begin{array}{c}1.0 \\
\chi^{2}=0.2, P=.90\end{array}$ & $\begin{array}{c}1.0 \\
\chi^{2}=0.4, P=0.80\end{array}$ & $\begin{array}{c}1.0 \\
\chi^{2}=0.1, P=0.90\end{array}$ & $\chi^{2}=\mathrm{NA}, P=\mathrm{NA}$ & $\chi^{2}=\mathrm{NA}, P=\mathrm{NA}$ \\
\hline
\end{tabular}

NA, not reporting results in instances of extremely high Wald $\chi^{2}$ (e.g. $\left.>1000\right)$ or extremely high $(>999.99)$ or low (<.001) odds ratio estimates or with no response variation. Reported $\mathrm{n}$ represent unweighted frequencies. All odds ratio estimates are weighted to be nationally representative of the given population and subpopulations in the coterminous 48 states of the US $95 \%$ confidence limits and $\chi^{2}$ statistics are adjusted for the sampling stratification, clustering, and weighting of the data.

OCD, obsessive-compulsive disorder.

The rate of co-occurring disorders among respondents with OCD in this sample is striking. The comorbidity rate in the present study $(93.4 \%)$ sub- stantially exceeds typical rates observed (50-75\%) in other adult OCD samples. ${ }^{[5,6]}$ The extraordinarily high rate of comorbidity may indicate that when African 
TABLE 6. Impairment scores of those with 12-month OCD and no history of OCD

\begin{tabular}{|c|c|c|c|c|c|c|c|c|c|c|c|c|c|c|c|c|}
\hline \multirow{3}{*}{$\frac{\text { Variables }}{\text { Days out of Role }}$} & \multicolumn{3}{|c|}{$\begin{array}{l}\text { Total OCD } \\
\text { sample }\end{array}$} & \multicolumn{3}{|c|}{ Caribbean blacks } & \multicolumn{3}{|c|}{ African Americans } & \multicolumn{2}{|c|}{ Race difference } & \multicolumn{3}{|c|}{$\begin{array}{l}\text { Any DSM disorder } \\
\text { other than OCD }\end{array}$} & \multicolumn{2}{|c|}{$\begin{array}{l}\text { Mean difference between } \\
\text { total OCD and any DSM } \\
\text { disorder other than OCD }\end{array}$} \\
\hline & \multirow{2}{*}{$\begin{array}{c}\text { Mean } \\
11.7\end{array}$} & \multicolumn{2}{|c|}{$\begin{array}{l}95 \% \mathrm{CL} \\
\text { for mean }\end{array}$} & \multirow{2}{*}{$\begin{array}{c}\text { Mean } \\
11.1\end{array}$} & \multicolumn{2}{|c|}{$\begin{array}{l}95 \% \text { CL } \\
\text { for mean }\end{array}$} & \multirow{2}{*}{$\begin{array}{c}\text { Mean } \\
17.4\end{array}$} & \multicolumn{2}{|c|}{$\begin{array}{l}95 \% \text { CL for } \\
\text { mean }\end{array}$} & \multirow{2}{*}{$\begin{array}{l}t \text {-value } \\
-1.15\end{array}$} & \multirow{2}{*}{$\frac{P \text {-value }}{0.25}$} & \multirow{2}{*}{$\frac{\text { Mean }}{6.2}$} & \multicolumn{2}{|c|}{$\begin{array}{l}95 \% \text { CL } \\
\text { for mean }\end{array}$} & \multirow{2}{*}{$\begin{array}{l}t \text {-value } \\
-4.30\end{array}$} & \multirow{2}{*}{$\frac{P \text {-value }}{<.01}$} \\
\hline & & 8.3 & 15.1 & & 6.9 & 15.4 & & 4.1 & 30.7 & & & & 5.4 & 6.9 & & \\
\hline Productivity & 8.0 & 6.2 & 9.9 & 7.9 & 5.7 & 10.1 & 9.5 & 3.5 & 15.4 & -0.5 & 0.59 & 4.8 & 4.3 & 5.2 & -4.31 & $<.01$ \\
\hline Cognition & 3.7 & 1.5 & 6.0 & 3.2 & 1.3 & 5.2 & 9.0 & -1.2 & 19.3 & -2.12 & 0.04 & 1. & 1.0 & 1.5 & -5.50 & $<.01$ \\
\hline Mobility & 6.1 & 3.6 & 8.6 & 5.6 & 3.1 & 8.1 & 11.1 & -1.0 & 23.2 & -1.6 & 0.12 & 2.4 & 2.0 & 2.8 & -5.29 & $<.01$ \\
\hline Self-care & 2.6 & 0.7 & 4.6 & 2.2 & 0.4 & 4.1 & 7.2 & -1.1 & 15.4 & -2.12 & 0.04 & 0.5 & 0.3 & 0.6 & -6.94 & $<.01$ \\
\hline Social & 3.0 & 1.5 & 4.6 & 2.6 & 1.2 & 3.9 & 7.8 & 0.2 & 15.5 & -2.5 & 0.02 & 0.8 & 0.6 & 0.9 & -6.38 & $<.01$ \\
\hline Family burden & 6.6 & 3.5 & 9.6 & 6.0 & 3.1 & 8.9 & 12.3 & 1.4 & 23.3 & -1.63 & 0.11 & 4.1 & 3.6 & 4.6 & -2.55 & .01 \\
\hline
\end{tabular}

$\mathrm{CL}$, confidence limit. All mean estimates are weighted to be nationally representative of the given population and subpopulations in the coterminous 48 states of the US Confidence limits and t-statistics are adjusted for the sampling stratification, clustering, and weighting of the data. All $t$ tests were two-sided.

OCD, obsessive-compulsive disorder.

TABLE 7. Severity of mental illness for 12-month OCD

\begin{tabular}{|c|c|c|c|c|c|c|c|c|c|c|c|}
\hline \multirow[b]{2}{*}{ Severity of mental illness } & \multicolumn{3}{|c|}{ Total OCD sample } & \multicolumn{3}{|c|}{ African Americans } & \multicolumn{3}{|c|}{ Caribbean blacks } & \multicolumn{2}{|c|}{ Race differences } \\
\hline & Freq & $\%$ & Std. error of \% & Freq & $\%$ & Std. error of $\%$ & Freq & $\%$ & Std. error of $\%$ & $\chi^{2}$ & $P$-value \\
\hline Mild & 16 & 14.5 & 3.5 & 8 & 14.2 & 3.7 & 8 & 18.0 & 8.0 & .2 & 0.92 \\
\hline Moderate & 29 & 39.8 & 4.8 & 18 & 40.5 & 4.7 & 11 & 32.6 & 22.1 & & \\
\hline Severe, serious & 25 & 45.6 & 5.9 & 23 & 45.3 & 5.8 & 2 & 49.4 & 28.7 & & \\
\hline
\end{tabular}

Reported frequencies are unweighted. All prevalence estimates are weighted to be nationally representative of the given population and subpopulations in the coterminous 48 states of the US Standard errors and $\chi^{2}$ statistic are adjusted for the sampling stratification, clustering, and weighting of the data.

$\chi^{2}$ significance test is based on 2 degrees of freedom.

OCD, obsessive-compulsive disorder.

TABLE 8. Severity of mental illness for OCD \& selected NSAL psychiatric disorders among African Americans and Caribbean blacks

\begin{tabular}{|c|c|c|c|c|c|c|c|c|c|c|c|}
\hline \multirow[b]{2}{*}{ Disorder } & \multicolumn{3}{|r|}{ Mild } & \multicolumn{3}{|c|}{ Moderate } & \multicolumn{3}{|c|}{ Severe, serious } & \multirow[b]{2}{*}{$\chi^{2}$} & \multirow[b]{2}{*}{$P$-value } \\
\hline & Freq & $\%$ & Std. error of \% & Freq & $\%$ & Std. error of \% & Freq & $\%$ & Std. error of \% & & \\
\hline $\mathrm{OCD}^{\mathrm{a}}$ & 16 & 14.1 & 5.1 & 29 & 36.7. & 7.0 & 25 & 49.2 & 8.1 & 28.7 & $<.01$ \\
\hline Any 12 -month disorder other than OCD & 330 & 39.9 & 2.0 & 358 & 43.9 & 2.2 & 121 & 16.2 & 1.9 & & \\
\hline Major depression ${ }^{\mathrm{a}}$ & 62 & 16.1 & 3.2 & 168 & 53.4 & 3.7 & 90 & 30.5 & 3.3 & & \\
\hline Dysthymia $^{\text {a }}$ & 16 & 16.4 & 4.7 & 47 & 44.1 & 5.0 & 38 & 39.5 & 4.9 & & \\
\hline Panic disorder ${ }^{\mathrm{a}}$ & 30 & 24.2 & 4.5 & 66 & 48.6 & 3.9 & 25 & 27.2 & 4.7 & & \\
\hline Agoraphobia with panic ${ }^{a}$ & 19 & 36.4 & 5.9 & 23 & 36.2 & 5.9 & 15 & 27.4 & 3.9 & & \\
\hline Social anxiety disorder ${ }^{\mathrm{a}}$ & 67 & 25.3 & 3.9 & 108 & 49.4 & 4.1 & 50 & 25.3 & 4.1 & & \\
\hline Generalized anxiety disorder ${ }^{\mathrm{a}}$ & 20 & 16.1 & 1.8 & 57 & 48.8 & 4.0 & 36 & 35.1 & 4.8 & & \\
\hline Post traumatic stress disorder ${ }^{a}$ & 49 & 27.8 & 3.3 & 87 & 43.2 & 4.3 & 40 & 29.0 & 4.3 & & \\
\hline
\end{tabular}

${ }^{\mathrm{a}}$ All comorbid disorders included.

Reported frequencies are unweighted. All prevalence estimates are weighted to be nationally representative of the given population and subpopulations in the coterminous 48 states of the US Standard errors and $\chi^{2}$ statistic are adjusted for the sampling stratification, clustering, and weighting of the data.

The $\chi^{2}$ value has 2 degrees of freedom and indexes the differences between OCD versus any 12-month disorder other than OCD across the severity categories. 
TABLE 9. 12 month OCD and 12 month service use ${ }^{\mathrm{a}}$

\begin{tabular}{|c|c|c|c|c|c|c|c|c|c|c|c|}
\hline & \multicolumn{3}{|c|}{ Total OCD sample $(n=70)$} & \multicolumn{3}{|c|}{ African Americans $(n=49)$} & \multicolumn{3}{|c|}{ Caribbean blacks $(n=21)$} & \multicolumn{2}{|c|}{ Race differences } \\
\hline & Freq & $\%$ & Std. error of \% & Freq & $\%$ & Std. error of \% & Freq & $\%$ & Std. error of \% & $\chi^{2}$ & $P$-value \\
\hline Any treatment & 26 & 40.8 & 7.8 & 18 & 38.4 & 8.1 & 8 & 66.9 & 18.0 & 2.1 & 0.20 \\
\hline Health services & 19 & 32.6 & 7.7 & 13 & 30.3 & 7.8 & 6 & 57.5 & 22.0 & 1.6 & 0.20 \\
\hline Mental health specialist & 14 & 19.6 & 6.0 & 10 & 20.7 & 6.5 & 4 & 8.2 & 5.8 & 1.7 & 0.20 \\
\hline Gen med professional & 13 & 27.1 & 7.4 & 11 & 22.8 & 7.4 & 2 & 49.3 & 25.3 & 1.1 & 0.30 \\
\hline Non-healthcare specialist & 13 & 25.1 & 7.1 & 11 & 26.6 & 7.7 & 2 & 9.4 & 7.7 & 1.9 & 0.16 \\
\hline Human services & 8 & 19.6 & 6.8 & 8 & 21.5 & 7.3 & 0 & 0 & 0 & $\mathrm{n} / \mathrm{a}$ & $\mathrm{n} / \mathrm{a}$ \\
\hline Complementary alternative & 5 & 5.5 & 3.2 & 3 & 5.1 & 3.4 & 2 & 9.4 & 7.7 & .3 & 0.60 \\
\hline SRI medication & 11 & 18.6 & 6.3 & 9 & 19.9 & 6.8 & 2 & 4.4 & 4.1 & 3.2 & 0.07 \\
\hline
\end{tabular}

a Sought services for emotions, nerves, mental health, and/or drug problems.

Reported frequencies are unweighted. All prevalence estimates are weighted to be nationally representative of the given population and subpopulations in the coterminous 48 states of the US Standard errors and $\chi^{2}$ statistics are adjusted for the sampling stratification, clustering, and weighting of the data.

SRI, serotonin reuptake inhibiting.

TABLE 10. 12-Month treatment seeking by severity combined African American \& Caribbean black sample with OCD

\begin{tabular}{|c|c|c|c|c|c|c|c|c|c|c|c|c|c|c|}
\hline \multirow[b]{2}{*}{ Treatment seeking } & \multicolumn{3}{|c|}{ Total } & \multicolumn{3}{|c|}{ Mild } & \multicolumn{3}{|c|}{ Moderate } & \multicolumn{3}{|c|}{ Severe } & \multirow[b]{2}{*}{$\chi^{2}$} & \multirow[b]{2}{*}{$P$-value } \\
\hline & Freq & $\%$ & $\begin{array}{l}\text { Std. error } \\
\text { of } \%\end{array}$ & Freq & $\begin{array}{c}\text { Row } \\
\%\end{array}$ & $\begin{array}{l}\text { Std. error } \\
\text { of row \% }\end{array}$ & Freq & $\begin{array}{c}\text { Row } \\
\%\end{array}$ & $\begin{array}{l}\text { Std. error } \\
\text { of row \% }\end{array}$ & Freq & $\begin{array}{c}\text { Row } \\
\%\end{array}$ & $\begin{array}{l}\text { Std. error } \\
\text { of row \% }\end{array}$ & & \\
\hline Any treatment & 26 & 40.8 & 7.8 & 2 & 3.9 & 3.2 & 10 & 33.0 & 12.2 & 14 & 59.5 & 11.4 & 10.6 & $<0.01$ \\
\hline Health services & 19 & 32.6 & 7.7 & 1 & 1.1 & 1.1 & 6 & 18.0 & 10.6 & 12 & 55.4 & 11.6 & 14.6 & $<0.01$ \\
\hline Specialty mental health & 14 & 19.6 & 6.0 & 0 & NA & NA & 4 & 4.9 & 3.7 & 10 & 38.8 & 11.3 & NA & NA \\
\hline General medical & 13 & 27.1 & 7.4 & 1 & 1.1 & 1.1 & 3 & 16.6 & 10.6 & 9 & 44.4 & 11.8 & 9.0 & 0.01 \\
\hline Non-healthcare specialist & 13 & 25.1 & 7.1 & 1 & 2.8 & 2.9 & 5 & 26.0 & 12.0 & 7 & 31.5 & 11.1 & 3.0 & 0.23 \\
\hline Human services & 8 & 19.6 & 6.8 & 0 & NA & NA & 2 & 15.6 & 10.7 & 6 & 29.4 & 11.0 & NA & NA \\
\hline $\begin{array}{l}\text { Complementary/ } \\
\text { Alternative medicine }\end{array}$ & 5 & 5.5 & 3.2 & 1 & 2.8 & 2.9 & 3 & 10.4 & 7.4 & 1 & 2.1 & 2.1 & 3.4 & 0.20 \\
\hline SRI medication & 11 & 18.6 & 6.3 & 1 & 0.5 & 0.5 & 6 & 25.9 & 11.8 & 4 & 18.0 & 8.7 & 3.5 & 0.18 \\
\hline
\end{tabular}

Reported frequencies are unweighted. All prevalence estimates are weighted to be nationally representative of the given population and subpopulations in the coterminous 48 states of the US Standard errors and $\chi^{2}$ statistic are adjusted for the sampling stratification, clustering, and weighting of the data.

$\chi^{2}$ significance test is based on 2 degrees of freedom.

SRI, serotonin reuptake inhibiting.

Americans and Caribbean blacks meet criteria for OCD, they experience more severe overall psychopathology. Additional studies are needed to further investigate this issue. Significantly higher-than-expected rates of panic disorder were found among Caribbean blacks with OCD compared to the AfricanAmerican respondents. ${ }^{[50]}$ also found higher rates of panic disorder among a pooled group of treatmentseeking African and Caribbean Americans with OCD compared to Caucasian patients. Unfortunately, it is impossible to discern if Caribbean Americans were primarily responsible for this elevated rate. The elevated prevalence of panic disorder among Caribbean blacks reported in the present study and by Friedman and associates may reflect an actual rate increase or it may reveal yet-to-be determined ethnicity/cultural issues that blur the distinctions between OCD and panic disorder.

Both overall mental illness severity and WHO-DASII disability ratings were very high among African Americans and Caribbean blacks with OCD. Respondents with OCD experienced significantly greater overall mental illness severity and greater disability on several WHO-DAS-II dimensions compared to pooled groups of persons with adult disorders other than OCD. Caribbean blacks with 12-month OCD were especially impaired on the cognition, self-care, and social WHO-DAS-II disability dimensions. Although OCD-specific severity and impairment were not assessed in this study, NSAL participants with OCD were substantially affected by mental health problems. This finding further supports the conclusion 
that OCD is a significant problem for blacks in America. Future studies using OCD-specific measures of severity and impairment are needed to better understand the severity and functional influences of OCD among these groups.

Socio-demographic correlates of OCD also reveal several interesting findings. Consistent with other studies of OCD sufferers, ${ }^{91]}$ lifetime and 12-month OCD risk was high among respondents who were unemployed or not in the labor force. Although the temporal relationship of OCD onset and employment difficulties is not possible to ascertain in this sample, it is likely that employment problems among persons with OCD primarily occur as a consequence of impairing OCD symptoms. Further, it is also likely that OCD symptoms are largely responsible for reduced educational attainment among persons with OCD found in the present and other studies. ${ }^{[9-11]}$ These findings provide further evidence of the substantial impact of OCD among American blacks.

The mean age of onset of OCD was later than expected for both the African American (32 years) and Caribbean black (30 years) sample. The average age of onset for the combined group in the present study is nearly 10 years later than rates found in previous studies of OCD. ${ }^{[52-54]}$ The reasons for this discordant rate are unclear but one may speculate that the later reported age of onset is indicative of a greater likelihood that environmental factors contributed to the etiology of OCD in this sample, given that the early onset subtype is known to be more familial ${ }^{[5,56]}$ and is possibly associated more often with specific genetic variants. ${ }^{[57]}$ Future family studies of African Americans and Caribbean blacks with OCD will help shed light on this issue.

Finally, despite the prevalence and marked impact of OCD in the present sample, service use over the past year among respondents meeting the 12-month OCD criteria was very limited. Although service use was substantially greater among those with more severe mental illness, the majority of persons with 12-month OCD were not using services. Service use in specialty mental health settings was very low (20\% of those with OCD), which is especially troubling since these settings are likely the only places where appropriate psychosocial treatment for OCD (cognitive-behavioral therapy) may be available. ${ }^{[48]}$ Additionally, only $20 \%$ of participants with OCD were taking recommended medications (SRIs) for OCD. ${ }^{[48]}$ In sum, it is likely that very few blacks in the United States with OCD are receiving evidence-based treatment and thus considerable efforts are needed to bring appropriate treatment to these groups.

The present study has limitations. First, although this is the largest study of Caribbean blacks and African Americans with OCD conducted to date, the relatively small number of African Americans and Caribbean blacks with OCD limits statistical power when attempting to compare these groups along OCD- related dimensions. These power limitations did not allow for the use of multivariate methods when calculating odds ratios for lifetime and 12-month OCD risk by race. Second, the cross-sectional nature of this study does not allow for ongoing assessment of temporal relationships between disorders or investigation of causative factors over time. Third, the NSAL did not assess OCD among whites, which obviously does not allow for comparison of rates and correlates of OCD between whites and blacks in the United States. Fourth, although the NSAL has a screening section for psychotic disorders, it did not fully assess schizophrenia or other nonaffective psychotic disorders. Finally, the use of the CIDI-SF for determining OCD diagnoses may not provide identical rates of OCD compared to rates observed using the full CIDI OCD diagnostic criteria.

Overall, the present report provides the most comprehensive and up-to-date information about OCD among African Americans and Caribbean blacks in the United States. It is clear that OCD is a significant public health problem in the American black community. Despite the high prevalence and substantial impairments associated with OCD among blacks, very little research has been conducted about the nature and treatment of OCD in this population. Future research is needed to further delineate differences in the heterogeneous black population with respect to OCD prevalence, symptom profiles, comorbidity, impairment, service utilization, and response to treatment.

Acknowledgments. Funding/Support: The NSAL is supported by the National Institute of Mental Health (NIMH; U01-MH57716) with supplemental support from the OBSSR (Office of Behavioral and Social Science Research) at the National Institutes of Health (NIH) and the University of Michigan. The authors have no other financial involvements related to this manuscript.

We appreciate the assistance provided in all aspects of the NSAL study by the Program for Research on Black Americans faculty and research staff including Phyllis Stillman, BA, Julie Sweetman, MS, and Myriam Torres, MS.

\section{REFERENCES}

1. American Psychiatric Association (APA). Diagnostic and statistical manual of mental disorders, 4th edition, Text Revision. Washington, DC: American Psychiatric Association; 2000.

2. Skoog G, Skoog I. A 40-year follow-up of patients with obsessive-compulsive disorder. Arch Gen Psychiatry 1999;56:121-127.

3. Stewart SE, Geller DA, Jenike M, Pauls D, Shaw D, Mullin B, Faraone SV. Long-term outcome of pediatric obsessive-compulsive disorder: a meta-analysis and qualitative review of the literature. Acta Psychiatr Scand 2004;110:4-13.

4. Rasmussen SA, Eisen JL. The epidemiology and clinical features of obsessive-compulsive disorder. In: Jenike MA, LB, Minichiello 
WE, editors. Obsessive-compulsive disorders: theory and management. Chicago: Year Book Medical Publishers, Inc; 1990:10-27.

5. Attiullah N, Eisen JL, Rasmussen SA. Clinical features of obsessive-compulsive disorder. Psychiatr Clin North Am 2000;23:469-491.

6. Brown TA, Campbell LA, Lehman CL. Current and lifetime cormorbidity of the DSM-IV anxiety and mood disorders in a large clinical sample. J Abnorm Psychol 2001;110:585-599.

7. Murray CJL, Lopez AD. The global burden of disease: a comprehensive assessment of mortality and disability from diseases, injuries, and risk factors in 1990 and projected to 2020. World Health Organization. Cambridge, MA: Harvard University Press; 1996.

8. Hollander E, Kwon JH, Stein DJ, Broatch J, Rowland CT, Himelein CA. Obsessive-compulsive and spectrum disorders: overview and quality of life issues. J Clin Psychiatry 1996;57(Suppl 8):3-6.

9. Andrews G, Henderson S, Hall W. Prevalence, comorbidity, disability and service utilisation: Overview of the Australian National Mental Health Survey. Br J Psychiatry 2001;178: $145-153$.

10. Karno M, Golding JM. Obsessive-compulsive disorder. In: Regier LNRDA, editor. Psychiatric disorder in America: the epidemiologic catchment area study. New York: Free Press; 1991:204-219.

11. Kringlen E, Torgersen S, Cramer V. A Norwegian psychiatric epidemiological study. Am J Psychiatry 2001;158:1091-1099.

12. Calvocoressi L, Lewis B, Harris M, Trufan SJ, Goodman WK, McDougle CJ, Price LH. Family accomodation in obsessivecompulsive disorder. Am J Psychiatry 1995;153:441-443.

13. Livingston-Van Noppen B, Rasmussen SA, Eisen J, McCartney L. Family function and treatment in obsessive-compulsive disorder. In: Jenike M, Baer L, Minichiello WE, editors. Obsessive-compulsive disorder: theory and treatment. Chicago: Yearbook Medical Publisher; 1990.

14. Clayton IC, Richards JC, Edwards CJ. Selective-attention in obsessive-compulsive disorder. J Abnorm Psychol 1999;108: 171-175.

15. Radomsky AS, Rachman S. Memory bias in obsessive-compulsive disorder(OCD). Behav Res Ther 1999;37:605-618.

16. Kessler RC, Berglund P, Demler O, Jin R, Merikangas KR, Walters EE. Lifetime prevalence and age-of-onset of DSM-IV disorders in the national comorbidity survey replication. Arch Gen Psychiatry 2005;62:593-602.

17. Robins LN, Helzer JE, Croughan J, Ratcliff KS. National Institute of Mental Heatlh Diagnostic Interview Schedule. Its history, characteristics, and validity. Arch Gen Psychiatry 1981; 38:381-389.

18. Weissman M, Bland R, Canino G, Greenwald S, Hwu H, Lee CK, Newman SC, Oakley-Browne MA, Rubio-Stipec M, Wickramaratne PJ, Wittchen H, Yeh E. The cross-national epidemiology of obsessive-compulsive disorder: the Cross National Collaborative Group. J Clin Psychiatry 1994;55(Suppl 3): $5-10$.

19. Fontenelle LF, Mendlowicz MV, Versiani M. The descriptive epidemiology of obsessive-compulsive disorder. ProgrNeuroPsychopharmacolBiol Psychiatry 2006;30:327-337.

20. Horwath E, Cohen RS, Weissman MM. Epidemiology of depressive and anxiety disorders, Chapter 16 . In: Tsuang MT, Tohen M, editors. Textbook in psychiatric epidemiology, 2nd edition. New York: Wiley; 2002:389-426.
21. Karadag F, Oguzhanoglu NK, Ozdel O, Atesci FC, Amuk T. OCD symptoms in a sample of Turkish patients: A phenomenological picture. Depress Anxiety 2006;23:145-152.

22. Breslau J, Aguilar S, Kendler KS, Su M, Williams D, Kessler RC. Specifying race-ethnic differences in risk for psychiatric disorder in a USA national sample. Psychol Med 2006;36:57-68.

23. Jackson JS, Neighbors HW, Nesse RM, Trierweiler SJ, Torres M. Methodological innovations in the National Survey of American Life. Int J Methods Psychiatr Res 2004;13:289-298.

24. Williams DR, Harris-Reid M. Race and mental health: Emerging patterns and promising approaches. In: Horwitz AV, Scheid TL, editors. A Handbook for the Study of Mental Health: Social Contexts, Theories, and Systems. New York, NY: Cambridge University Press; 1999:295-314.

25. Jackson JS, Torres M, Caldwell CH, Neighbors HW, Nesse RM, Taylor RJ, Trierweiler SJ, Williams DR. The National Survey of American Life: a study of racial, ethnic and cultural influences on mental disorders and mental heath. Int J Methods Psychiatr Res 2004;13:196-207.

26. Williams DR, Lavizzo-Mourey R, Warren RC. The concept of race and health status in America. Public Health Rep 1994;109:26-41.

27. Logan JR, Deane G. Black diversity in metropolitan America. Albany, NY: The Mumford Center for Comparative Urban and Regional Research; 2003.

28. Kasinitz P. Caribbean New York: black immigrants and the politics of race. Ithaca, N.Y.: Cornell University Press; 1992.

29. Hemingway H, Whitty CJM, Shipley M, Stansfeld MS, Brunner E, Fuhrer R, Marmot M. Psychosocial risk factors for coronary disease in white, South Asian and Afro-Caribbean civil servants: The Whitehall II study. Ethn Dis 2001;11:391-400.

30. Selten JP, Slaets JP, Kahn RS. Schizophrenia in Surinamese and Dutch Antillean immigrants to The Netherlands: evidence of an increased incidence. Psychol Med 1997;27:807-811.

31. van Os J, Takei N, Castle DJ, Wessely S, Der G, Macdonald AM, Murray RM. The incidence of mania: time trends in relation to gender and ethnicity. Soc Psychiatry Psychiatr Epidemiol 1996;31:129-136.

32. Williams DR. Race, stress, and mental health: Findings from the Commonwealth Minority Health Survey. In: Hogue C, Hargraves M, Scott-Collins K, editors. Minority Health in America: Findings and Policy Implication from the Commonwealth Fund Minority Health Survey. Baltimore, MD: Johns Hopkins University Press; 2000:209-243.

33. Williams DR, Gonzalez HM, Neighbors H, Nesse R, Abelson JM, Sweetman J, Jackson JS. Prevalence and distribution of major depressive disorder in African Americans, Caribbean Blacks, and Non-Hispanic Whites: Results from the National Survey of American Life. Arch Gen Psychiatry 2007;64:307-315.

34. Breslau J, Kendler KS, Su M, Gaxiola-Aguilar S, Kessler RC. Lifetime risk and persistence of psychiatric disorders across ethnic groups in the United States. Psychol Med 2005;35: 317-327.

35. Robins LN, Regier DA. Psychiatric disorders in America: the epidemiolgic Catchment area study. New York, NY: Collier Macmillan Publishers; 1991.

36. Neighbors H, Williams DR. The epidemiology of mental disorder: 1985 to 2000. In: Braithwaite RL, Taylor SE, editors. Health issues in the black community. San Francisco, CA: JosseyBass; 2001:99-128.

37. Goodwin R, Koenen KC, Hellman F, Guardino M, Struening E. Helpseeking and access to mental health treatment for obsessivecompulsive disorder. J Clin Psychopharmacol 2002;18:185-192. 
38. Williams DR, Jackson JS. Race/Ethnicity and the 2000 census: Recommendations for African American and other black populations in the United States. Am J Public Health 2000;90: $1728-1730$.

39. Williams DR, Takeuchi D, Adair R. Socioeconomic status and psychiatric disorder among blacks and whites. Social Forces 1992;71:179-194.

40. Heeringa SG, Wagner J, Torres M, Duan N, Adams T, Berglund P. Sample designs and sampling methods for the Collaborative Psychiatric Epidemiology Studies (CPES). Int J Methods Psychiatric Res 2004;13:221-240.

41. Kessler RC, Ustan TB. The World Mental Health (WMH) Survey Initiative Version of the World Health Organization (WHO) Composite Diagnostic Interview (CIDI). Int J Methods Psychiatr Res 2004;13:93-121.

42. Kessler RC, Andrews G, Mroczek D, Ustun B, Witchen H. The World Health Organization Composite International Diagnostic Interview Short-Form (CIDI-SF). Int J Methods Psychiatr Res 1989;7:171-185.

43. United States Census Bureau. 2007. Census regions and divisions of the United States. In: Administration DoCEaS, editor.

44. Economic Research Service. 2004. Measuring rurality: Ruralurban continuum codes. In: Agriculture USDo, editor.

45. Rehm J, Ustun B, Saxena S, Nelson CB, Chatterji S, Ivis F, Adlaf E. On the development and psychometric testing of the WHO screening instrument to assess disablement in the general population. Int J Methods Psychiatr Res 1999;8: $110-123$.

46. Leon AC, Olfson M, Portera L, Farber L, Sheehan DV. Assessing psychiatric impairment in primary care with the Sheehan Disability Scale. Int J Psychiatry Med 1997;27: 93-105.

47. March JS, Frances A, Carpenter D, Kahn D. The expert consensus guidelines series: treatment of obsessive-compulsive disorder. J Clin Psychiatry 1997;58(Suppl 4): 1-72.
48. SAS Institute S. SAS/STAT User's Guide, Version 9.1.3. Cary, NC: SAS Institute, Inc; 2006.

49. Friedman S, Smith LC, Halpern B, Levine C, Paradis C, Viswanathan R, Trappler B, Ackerman R. Obsessive-compulsive disorder in a multi-ethnic urban outpatient clinic: initial presentation and treatment outcome with exposure and ritual prevention. Behav Ther 2003;34:397-410.

50. Leon AC, Portera L, Weissman MM. The Social Costs of Anxiety Disorders. Br J Psychiatry 1995;166:19-22.

51. Burke KC, Burke JD, Regier DA. Age of onset of selected mental disorders in five community populations. Arch Gen Psychiatry 1990;47:511-518.

52. Noshirvani HA, Kasvikis Y, Marks IA, Tsakiris F, Monteiro WO. Gender-divergent etiological factors in obsessive-compulsive disorder. Br J Psychiatry 1991;148:260-263.

53. Rasmussen SA, Eisen JL. The epidemiology and clinical features of obsessive compulsive disorder. J Clin Psychiatry 1992;53:743-758.

54. Nestadt G, Samuels J, Riddle M, Bienvenu III OJ, Liang KY, LaBuda M, Walkup J, Grados M, Hoehn-Saric R. A family study of obsessive-compulsive disorder. Arch Gen Psychiatry 2000;57:358-363.

55. Pauls DL, Alsobrook III JP, Goodman W, Rasmussen S, Leckman JF. A family study of obsessive-compulsive disorder. Am J Psychiatry 1995;142:76-84.

56. Hanna GL, Veenstra-vander Weele J, Cox NJ, Boehnke M, Himle JA, Curtis GC, Leventhal BL, Cook EH. Genome-wide linkage analysis of families with obsessive-compulsive disorder ascertained through pediatric probands. Am J Med Gen (Neuropsychiatric Gen) 2002;114:541-552.

57. Jackson JS, Williams DR, Neighbors HW, Nesse R, Torres M, Trierweiler SJ. In press. Lifetime and 12-month prevalence of DSM-IV disorders among African Americans, Caribbean Blacks, and Non-Hispanic Whites: results from the National Survey of American Life (NSAL). Int J Methods Psychiatr Res. 